\title{
Jurist-Diction
}

Volume 2 No. 5, September 2019

Histori artikel: Submit 28 Juli 2019; Diterima 23 Agustus 2019; Diterbitkan online 1 September 2019.

\section{Sewa Guna Usaha Pesawat Udara Menurut Konvensi Cape Town 2001 dan Implementasinya dalam Hukum Nasional}

\author{
Erlisa Akhlakul Karimah \\ Erlisa061197@gmail.com \\ Universitas Airlangga
}

\begin{abstract}
The number of airplane enthusiasts continue to increase every year compared to other modes of transportation. With the increase in airplane enthusiasts, an obligation arises for airline companies to continue to rejuvenate the aircrafts by renewing their fleet to support and maintain the quality of services provided. In contrast to other types of transportation, airplanes are capital-intensive objects, which means procurement and operational costs require no small amount of money. Based on this fact, in addition to sales agreement and rent agrement, there are several choices of new types of agreements that are more utilized by airlines. For example, transactions through aircraft leasing. However, from international conventions and national regulations, no specific arrangements have been found governing aircraft leasing. Then, legal protection by providing security rights for the parties in an aircraft leasing business also needs to be traced back, in order to realize justice and legal certainty in contracting. In order to answer these problems, the researcher uses the type of doctrinal legal research with the statute approach, the conceptual approach, and the comparative approach. In this study, the researcher tried to discuss the specific provisions regarding aircraft leasing that were in the Cape Town Convention 2001 and connected them with national law. In addition, the researcher will discuss the arrangements relating to the protection of material security rights granted to the parties in the event of default. From this study, it can be concluded that there are no national rules regarding aircraft leasing and security rights for aircraft.
\end{abstract}

Keywords: Leasing; Aircraft; International Law; Fiduciary Guarantees; IDERA.

\begin{abstract}
Abstrak
Jumlah peminat pesawat udara terus meningkat tiap tahunnya jika dibandingkan dengan transportasi lainnya. Dengan meningkatnya peminat pesawat udara, timbul suatu kewajiban bagi perusahaan maskapai penerbangan untuk terus meremajakan pesawat udara dengan memperbarui armadanya demi menunjang dan menjaga kualitas jasa yang diberikan. Berbeda dengan jenis transportasi lainnya, pesawat udara merupakan objek yang bersifat padat modal, yang dimaksud dengan padat modal adalah untuk pengadaan dan biaya operasionalnya membutuhkan biaya yang tidak sedikit. Berdasarkan fakta ini, selain jual-beli dan sewa menyewa terdapat beberapa pilihan jenis perjanjian baru banyak yang lebih dimanfaatkan oleh maskapai penerbangan. Sebagai contoh, menggunakan transaksi melalui sewa guna usaha pesawat udara. Namun, dari konvensi internasional dan peraturan nasional, belum ditemukan adanya pengaturan yang spesifik mengatur mengenai sewa guna usaha pesawat udara. Kemudian, perlindungan hukum dengan cara pemberian hak jaminan kebendaan bagi para pihak dalam sewa guna usaha pesawat udara juga perlu untuk ditelusuri kembali, guna mewujudkan keadilan dan kepastian hukum dalam berkontrak. Dalam rangka menjawab permasalahan tersebut, Peneliti menggunakan tipe penelitian hukum doktrinal dengan pendekatan perundang-undangan (statute approach), pendekatan konseptual (conceptual approach), dan pendekatan perbandingan (comparative approach). Dalam penelitian ini, Peneliti mencoba membahas ketentuan-ketentuan khusunya mengenai sewa guna usaha pesawat udara yang ada di dalam Konvensi Cape Town 2001 dan menghubungkannya dengan hukum nasional. Selain itu, peneliti akan membahas mengenai pengaturan terkait perlindungan hak jaminan kebendaan yang diberikan kepada para pihak apabila terjadi pailit atau cidera janji (wanprestasi). Dari penelitian ini, dapat disimpulkan bahwa belum ada aturan nasional mengenai sewa guna usaha dan hak jaminan kebendaan atas pesawat udara. Kata Kunci: Sewa Guna Usaha; Pesawat Udara; Hukum Internasional; Jaminan Kebendaan; IDERA.
\end{abstract}




\section{Pendahuluan}

Transportasi udara, khususnya di Indonesia, telah menjadi salah satu pilihan transportasi yang memiliki banyak peminat di antara jenis transportasi yang lain, transportasi darat dan laut. Dengan waktu tempuh yang lebih singkat dan memiliki daya tampung yang besar menjadi alasan bagi masyarakat Indonesia memilih untuk menggunakan pesawat udara. Berdasarkan fakta tersebut, menjadi suatu kewajiban bagi maskapai agar selalu dapat menjaga kualitas jasa yang diberikan bagi konsumennya. Salah satu cara bagi maskapai untuk menjaga kualitas jasa yang diberikan adalah menjaga kualitas pesawat udara yang dimilikinya agar tetap terawat. Pesawat udara yang dimiliki oleh maskapai penerbangan dapat dijaga kualitasnya apabila maskapai selalu melakukan peremajaan terhadap pesawatnya. Melakukan peremajaan pesawat bukanlah hal yang mudah bagi maskapai penerbangan, dikarenakan pesawat merupakan suatu barang yang padat modal. Apabila melalui Jual-beli pesawat udara secara langsung dirasa cukup memberatkan maskapai. Sehingga, maskapai penerbangan menggunakan cara lain yaitu dengan melakukan kegiatan sewa guna usaha atau leasing pesawat udara. Walaupun leasing pesawat udara membawa banyak kelebihan khususnya bagi maskapai namun tidak dapat dipungkiri bahwa leasing pesawat udara juga memiliki kelemahan. Kelemahannya adalah masih banyak sengketa dalam transaksi pesawat udara yang disebabkan karena masih kurang implementasi peraturan terkait leasing sendiri.

Hingga kini masih belum ada pengaturan yang spesifik ada terkait leasing dan pemberian jaminan pesawat udara, khususnya di Indonesia. Oleh karena itu, Peneliti akan menganalisis mengenai kontrak leasing yang bersifat internasional atau nasional yang dilakukan di Indonesia terkait pesawat udara yang telah atau belum sesuai dengan praktik dan ketentuan hukum internasional. Melihat adanya ketertarikan Indonesia terhadap diadopsinya konvensi internasional ini, maka tujuan dari penelitian ini dalam rangka mengetahui pengaruh Konvensi Cape Town 2001 terhadap prosedur sewa guna usaha pesawat udara dan dibandingkan dengan hukum nasional yang telah diterapkan di Indonesia. Terutama dalam hal leasing pesawat udara dan perlindungan kepentingan para pihak yang terikat dalam perjanjian. 


\section{Metode Penelitian}

Tipe penelitian hukum yang digunakan Peneliti adalah penelitian Hukum Doktrinal, yaitu Peneliti menyediakan ekspos sistematis terhadap peraturan yang mengatur kategori hukum tertentu, ${ }^{1}$ menganalisis hubungan antar peraturan, yakni dalam penelitian ini terkait dengan aturan mengenai leasing pesawat Udara dalam perspektif hukum internasional dan hukum nasional. Selain itu, Peneliti juga menjelaskan area yang mengalami hambatan seperti dalam penyelesaian sengketa-sengketanya dan studi kasus, dan bahkan Peneliti akan memperkirakan perkembangan mendatang di Indonesia khususnya terkait sewa guna usaha atau leasing pesawat Udara;

Pendekatan yang digunakan dalam penelitian ini adalah pendekatan perundang-undangan atau statute approach, pendekatan konseptual atau conceptual approach, dan pendekatan perbandingan atau comparative approach. Pendekatan yang pertama adalah pendekatan perundang-undangan atau Statute Approach. Pendekatan perundang-undangan (Statute Approach) merupakan penelitian yang mengutamakan bahan hukum yang berupa peraturan perundang-undangan sebagai bahan acuan dasar dalam melakukan penelitian. ${ }^{2}$

Pendekatan perundang-undangan (statute approach) di gunakan untuk meneliti peraturan perundang-undangan yang dalam penormaannya masih terdapat kekurangan baik dalam tataran teknis atau dalam pelaksanaannya di lapangan. Pendekatan ini dilakukan dengan menelaah semua peraturan perundang-undangan yang bersangkut paut dengan permasalahan (isu hukum) yang sedang dihadapi. ${ }^{3}$ Diterapkannya pendekatan perundang-undangan atau statute approach dalam penelitian ini dikarenakan, dalam penelitian ini akan membahas mengenai hubungan antara ketentuan-ketentuan dalam Konvensi Cape Town 2001 dan hukum nasional Indonesia. Kedua aturan tersebut akan ditelaah mengenai pengakuan dan penerapannya di Indonesia.

\footnotetext{
1 Peter Mahmud Marzuki, Penelitian Hukum (Kencana Prenada Media 2005).[32].

2 Peter Mahmud Marzuki, Op.Cit. [93-137].

3 ibid.
} 
Pendekatan yang kedua adalah pendekatan konseptual atau conceptual approach. Pendekatan konseptual (conceptual approach) merupakan jenis pendekatan dalam penelitian hukum yang memberikan sudut pandang analisa penyelesaian permasalahan dalam penelitian hukum dilihat dari aspek konsep-konsep hukum yang melatarbelakanginya, atau bahkan dapat dilihat dari nilai-nilai yang terkandung dalam penormaan sebuah peraturan kaitannya dengan konsep-konsep yang digunakan. ${ }^{4}$ Sebagian besar jenis pendekatan ini dipakai untuk memahami konsep-konsep yang berkaitan dengan penormaan dalam suatu perundangundangan apakah telah sesuai dengan ruh yang terkandung dalam konsep-konsep hukum yang mendasarinya. Pendekatan ini beranjak dari pandangan-pandangan dan doktrin-doktrin yang berkembang di dalam ilmu hukum. Pendekatan ini menjadi penting sebab pemahaman terhadap pandangan/doktrin yang berkembang dalam ilmu hukum dapat menjadi pijakan untuk membangun argumentasi hukum ketika menyelesaikan isu hukum yang dihadapi. Pandangan/doktrin akan memperjelas ideide dengan memberikan pengertian-pengertian hukum, konsep hukum, maupun asas hukum yang relevan dengan permasalahan. ${ }^{5}$ Diterapkannya pendekatan konseptual atau conseptual approach dalam penelitian ini dikarenakan, dalam penelitian ini akan membahas mengenai penormaan peraturan-peraturan nasional maupun internasional terkait konsep dari sewa guna usaha (leasing). Selain membahas mengenai penormaan terkait konsep sewa guna usaha (leasing) dalam penelitian ini juga akan membahas mengenai analisa penyelesaian masalah terkait konsepkonsep sewa guna usaha (leasing) dalam hukum internasional dan hukum nasional.

Pendekatan yang ketiga adalah pendekatan perbandingan (comparative approach). Pendekatan perbandingan merupakan jenis pendekatan yang dilakukan dengan membandingkan peraturan hukum ataupun putusan pengadilan di suatu negara dengan peraturan hukum yang ada di negara lain (baik satu negara atau

4 Saiful Anam \& Partners, 'Pendekatan Perundang-Undangan (Statute Approach) dalam Penelitian Hukum', (Legal Opinion 2017) < https://www.saplaw.top/pendekatan-perundang-undangan-statute-approach-dalam-Penelitian-hukum/>, accessed on 15 Oktober 2018.

5 ibid. 
lebih). ${ }^{6}$ Perbandingan yang dilakukan harus mengenai hal yang sama, yaitu dalam penelitian ini mengenai hukum mengenai pesawat udara. Jadi, selain pendekatan yang berdasarkan peraturan dan konsep, pada penelitian ini juga akan membahas mengenai perbandingan hukum yang khususnya terkait keberlakuan hukum pesawat udara yang ada di Indonesia dengan hukum yang berlaku di negara lain.

\section{Pengaturan Mengenai Sewa Guna Usaha Pesawat Udara menurut Konvensi Internasional}

Sebelum Konvensi Cape Town 2001 dibentuk, terdapat 2 konvensi lain yang telah mengatur mengenai pesawat udara, yaitu:

1. Konvensi Hague 1970: Dalam konvensi ini hanya mengatur mengenai pemberian kewenangan bagi masing-masing negara untuk memberikan hukuman bagi pelanggaran-pelanggaran yang terjadi di dalam pesawat. Kelemahan dari Konvensi Hague 1970 adalah konvensi ini tidak membahas mengenai transaksi pesawat udara secara internasional dan penerapan hukum nasional masing-masing negara anggota tidak dapat disamakan.

2. Konvensi Jenewa 1948: Dalam konvensi ini hanya mengatur mengenai badan pesawat, karena mesin pesawat dianggap sebagai satu kesatuan dengan badan pesawat. Kelemahan dari konvensi ini adalah mesin pesawat harusnya diatur terpisah dengan badan pesawat dikarenakan apabila terdapat pihak yang hanya ingin membeli mesin pesawat saja atau sebaliknya.

Dari kelemahan yang ada pada konvensi-konvensi sebelumnya, maka digagaslah untuk membentuk suatu ketentuan internasional yang mengatur mengenai segala sesuatu terkait pesawat udara. Terdapat dua konvensi internasional yang mengatur mengenai pesawat udara, yaitu Konvensi Cape Town 2001 dan Konvensi Chicago 1944. Dalam Konvensi Cape Town 2001, mengatur mengenai kepentingan internasional yang melekat pada pesawat udara. International interest atau kepentingan

\footnotetext{
6 Ngobrolin Hukum, 'Pendekatan Dalam Penelitian Hukum' (Ngobrolin Hukum 2013) $<$ https://ngobrolinhukum.wordpress.com/2013/12/16/pendekatan-dalam-penelitian-hukum/>, accessed on 27 Juni 2019
} 
internasional didefinisikan sebagai kepentingan yang timbul terhadap "objek pesawat udara" atau "aircraft objects" yang meliputi: airframes, aircraft engines and helicopters (rangka pesawat udara, mesin pesawat udara, dan helikopter);

Pada Protokol Konvensi Cape Town 2001, memberi perluasan terhadap definisi International Interest dengan mencakup segala perjanjian penjualan yang aktual maupun yang akan dilaksanakan ("actual or prospective aircraft sale agreement"). ${ }^{7}$ Kepentingan internasional dapat timbul dari tiga macam perjanjian, yaitu Security Agreement, Title Reservation Agreement, dan Leasing Agreement. "Security Agreement" adalah perjanjian ketika pemberi jaminan (chargor) memberikan jaminan kepada pihak yang diberi jaminan (chargee) atas suatu kepentingan (security interest-termasuk kepentingan jaminan kepemilikan). ${ }^{9}$ "Title Reservation Agreement" adalah perjanjian dalam hal penjualan objek perjanjian (pesawat udara) yang harus diikuti dengan syarat, bahwa hak kepemilikan atas objek perjanjian tidak akan diberikan kepada pembeli sampai pemenuhan kondisi atau kondisi yang dinyatakan dalam

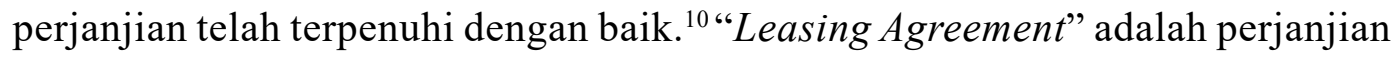
yang terdapat di dalamnya pemberi sewa atau lessor memberikan hak untuk memiliki atau menguasai suatu objek (dengan atau tanpa opsi untuk membeli) kepada orang lain yaitu seorang penyewa atau lessee sebagai imbalan atas sewa atau pembayaran lainnya. ${ }^{11}$

Selain kepentingan internasional dalam Konvensi Cape Town 2001 juga mengatur mengenai kepentingan nasional atau National Interest. National Interest (Kepentingan Nasional) merupakan jaminan perlindungan kepentingan nasional yang dapat didaftarkan berdasarkan hukum nasional masing-masing negara anggota yang dapat dimungkinkan didaftarkan sebagai kepentingan internasional.

\footnotetext{
7 Article 7 Cape Town Convention 2001 and Protocol of Cape Town Convention, Article III.

8 Roy Goode, 'The International Interest as an Autonomous Property Interest', (2004) European Review of Private Law I. [21].

9 Chapter I-Article 1 point (ii) Cape Town Convention 2001

${ }^{10}$ Chapter I-Article 1 point (ll) Cape Town Convention 2001

11 Chapter I-Article 1 point (y) Cape Town Convention 2001
} 
Dalam Konvensi Cape Town 2001 telah mengatur mengenai definisi, pengakuan, dan ruang lingkup bagi National Interest yang dimaksud dalam konteks ini. Definisi mengenai National Interest diatur dalam Chapter I-Article 1 point (r): “" "national interest" means an interest held by a creditor in an object and created by an internal transaction covered by a declaration under Article 50(1)". Dalam Konvensi Cape Town 2001, memberi kewenangan bagi para pihak dalam perjanjian untuk dapat mendaftarkan kepentingan nasional mereka sesuai dengan hukum nasional negaranya, dengan tujuan agar kepentingan tersebut diakui sebagai kepentingan internasional. Namun, setelah pendaftaran kepentingan tersebut telah diakui maka pihak tersebut memiliki kewajiban untuk melakukan deklarasi bahwa kepentingan nasional yang didaftarkan telah diakui sebagai kepentingan internasional.

Agar seluruh kepentingan tersebut (baik kepentingan internasional maupun kepentingan lain) mendapatkan perlindungan hukum, maka terdapat syaratsyarat formal yang harus dipenuhi terlebih dahulu. Syarat-syarat formal tersebut diatur dalam Pasal 7 Konvensi Cape Town 2001. ${ }^{12}$ Dalam pasal ini, terdapat suatu keharusan bagi pihak yang membuat perjanjian untuk memenuhi beberapa syarat formal agar dapat mengajukan permohonan perlindungan kepentingan, dengan syarat-syarat formal ${ }^{13}$ (apabila dirangkum), ialah:

a. Diajukan secara tertulis melalui sistem daring atau online; Kepentingan internasional yang timbul dari objek perjanjian harus dimohonkan secara online melalui daring (website $\left.{ }^{14}\right)$ pendaftaran internasional atau international registry;

b. Perjanjian harus berkaitan dengan objek yang dimiliki oleh lembaga penjamin (chargor), penjual (seller) dalam jual beli bersyarat atau lessor dalam leasing yang memiliki kewenangan untuk terikat pada suatu kontrak;

${ }^{12}$ Article 7 - Formal Requirements

An interest is constituted as an international interest under this Convention where the agreement creating or providing for the interest:

(a) is in writing;

(b) relates to an object of which the chargor, conditional seller or lessor has power to dispose;

(c) enables the object to be identified in conformity with the Protocol; and

(d) in the case of a security agreement, enables the secured obligations to be determined, but without the need to state a sum or maximum sum secured.

13 Roy Goode, Loc.Cit.

${ }_{14}$ International Aircraft Registry, 'International Registry of Mobile Assets)' < https://www. internationalregistry.aero/ir-web/>, accessed on 27 Juni 2019 
c. Aset yang merupakan objek dari perjanjian harus dapat diidentifikasi;

d. Kewajiban-kewajiban yang timbul dari perjanjian harus dapat diidentifikasi.

\section{Pengaturan Mengenai Pendaftaran Pesawat Udara menurut Konvensi Internasional}

Pada bagian awal ketentuan dalam Konvensi Cape Town 2001 pada dasarnya memuat ketentuan-ketentuan umum yang berkaitan dengan hak jaminan kebendaan yang diakui secara internasional menyangkut kepentingan internasional atau International Interest. Namun, semakin ke bagian inti substansi konvensi ini semakin spesifik mengatur mengenai permohonan timbulnya perlindungan terkait kepentingan internasional dari suatu pesawat udara melalui sistem pendaftaran internasional atau international registry.

Sebelum pengaturan terkait sistem registrasi internasional yang secara spesifik diatur dalam Konvensi Cape Town 2001, terdapat ketentuan dalam konvensi sebelumnya yang menyinggung mengenai pendaftaran pesawat udara. Konvensi tersebut adalah Convention on International Civil Aviation (selanjutnya disebut Konvensi Chicago, 1944). Dalam Pasal 17 hingga 21 Konvensi Chicago 1944, lebih dahulu mengatur mengenai pendaftaran pesawat udara dibanding Konvensi Cape Town 2001. ${ }^{15}$

Pada Chapter III Konvensi Chicago 1944, dinyatakan bahwa menjadi suatu kewajiban dari pesawat udara untuk memiliki sertifikat pendaftaran (sebagai bentuk tanda kebangsaan). ${ }^{16}$ Menurut konvensi ini, pesawat udara dinyatakan tidak sah untuk melakukan penerbangan internasional kecuali telah memiliki tanda kebangsaan dan tanda pendaftaran pada suatu negara. Ketentuan yang ada di Konvensi Chicago 1944, juga mengatur bahwa sebuah pesawat udara tidak diperbolehkan untuk memiliki registrasi atau tanda kebangsaan ganda. Namun, dalam ketentuan ini juga menyatakan bahwa masih dimungkinkan untuk mengubah registrasi pesawat dari satu negara

${ }^{15}$ Donal Patrick Hanley, Aircraft Operating Leasing-A Legal and Practical Analysis in The Context of Public and Private International Air Law, (Wolters Kluwer Law\&Business 2012). [38].

${ }_{16}$ Article 17 of Chicago Convention 1944

Aircraft have the nationality of the State in which they are registered. 
berubah menjadi negara lainnya. ${ }^{17}$ Baik aturan mengenai pendaftaran registrasi atau tanda kebangsaan maupun aturan mengenai perubahan registrasi pesawat didasarkan pada hukum nasional masing-masing negara anggota konvensi ini. ${ }^{18}$

Antara peraturan pendaftaran tanda kebangsaan pesawat udara menurut Konvensi Chicago 1944 dengan peraturan sistem registrasi internasional menurut Konvensi Cape Town 2001 merupakan dua peraturan yang berbeda. Perbedaan antara pengaturan pendaftaran pesawat udara yang ada di Konvensi Chicago 1944 dan Konvensi Cape Town 2001 adalah apabila dalam Konvensi Chicago 1944, mengatur mengenai pendaftaran registrasi atau tanda kebangsaan bagi suatu pesawat udara. Sedangkan, pendaftaran internasional yang dimaksud dalam Konvensi Cape Town 2001 adalah pendaftaran Kepentingan internasional atau International Interest dan Kepentingan-Kepentingan Non-Konsensual yang telah dibagi menjadi beberapa bagian pengaturan (dari Chapter IV hingga Chapter VII). Kepentingankepentingan tersebut timbul dari adanya suatu perjanjian internasional yang menjadikan pesawat udara sebagai objek perjanjiannya. Dan tujuan didaftarkannya kepentingan-kepentingan itu agar mendapatkan perlindungan oleh hukum.

Sistem pendaftaran internasional dalam Konvensi Cape Town 2001 dilakukan melalui sistem daring atau online. Jadi, seluruh sistem yang digunakan merupakan sistem yang seluruhnya bersifat otomatis atau computerized. Bukan tanpa alasan mengapa sistem pendaftaran internasional ini bersifat otomatis. Tujuannya adalah agar dalam pendaftaran internasional tersebut tidak ada intervensi manusia dalam hal pengajuan pendaftaran, dampak dari pendaftaran, penerimaan permintaan dan penerimaan sertifikat pendaftaran yang dikeluarkan. ${ }^{19}$ Hal tersebut yang menjadikan akan lebih mudahnya pemeriksaan dan pengakuan oleh negara lain terhadap pendaftaran pesawat udara secara internasional.

\footnotetext{
${ }^{17}$ Article 18 of Chicago Convention 1944

An aircraft cannot be validly registered in more than one State, but its registration may be changed from one State to another.

18 Article 19 of Chicago Convention 1944

The registration or transfer of registration of aircraft in any contracting State shall be made in accordance with its laws and regulations.

19 Prita Amalia, Industri Penerbangan di Indonesia, (Refika Aditama 2016). [103].
} 
Terkait negara yang menjadi pusat pendaftaran kepentingan internasional, sudah lebih dari seribu perusahaan maskapai penerbangan yang telah mendaftarkan perlindungan kepentingan internasionalnya dan menjadikan basis operasi komersial mereka pada negara Irlandia. Irlandia telah memperoleh reputasi sebagai tujuan ekonomi yang ramah bisnis. Banyak perusahaan maskapai penerbangan yang mempercayakan pusat operasionalnya di Irlandia dimulai sejak tahun 1975. ${ }^{20}$ Meskipun pusat pendaftaran operasional internasional pesawat udara ada di Irlandia, perusahaan maskapai penerbangan tidak perlu selalu harus pergi ke Irlandia, karena pendaftaran kepentingan internasional dari transaksi internasional dapat dilakukan melalui sistem online atau melalui daring. Website pendaftaran kepentingan internasional dapat diakses dan pendaftaran internasional ini dapat dilakukan dalam 24 jam sehari, 7 hari seminggu, secara otomatis. Walaupun dalam sesekali sistem akan dimatikan dalam waktu yang singkat untuk melakukan maintenance dan memperbaiki sistem yang tidak berfungsi. ${ }^{21}$

\section{Ratifikasi Konvensi Cape Town 2001 dalam Hukum Nasional}

Setelah disahkannya Konvensi Cape Town 2001 pada konferensi diplomatik yang diselenggarakan di Cape Town, Afrika Selatan pada bulan November 2001, menjadi angin segar bagi negara-negara yang membutuhkan wadah hukum khususnya terkait pesawat udara. Ratifikasi merupakan salah satu syarat yang diatur dalam Konvensi Cape Town 2001 untuk menjadi pintu masuk agar suatu negara dapat terikat menjadi negara anggota dan dapat menerapkan ketentuan yang ada dalam Konvensi Cape Town 2001 ini. ${ }^{22}$

Jadi, dengan diratifikasinya Konvensi Cape Town 2001 oleh Indonesia maka Indonesia menjadi salah satu negara anggota yang terikat dengan aturan untuk melaksanakan semua ketentuan kewajiban internasional yang diatur

\footnotetext{
${ }^{20}$ Ireland Ibec, 'Iris Advantage - Reasons for choosing Ireland as a destination', Ireland Ibec2018)<https://www.aircraftleasingireland.ie/Sectors/ALI/ALI.nsf/vPages/Aircraft_leasing_in_ Ireland irish-advantage! OpenDocument>, accessed on 10 Mei 2019

${ }^{21}$ Roy Goode, Op.Cit., [7]

${ }^{22}$ Chapter XIV - Article 47 Cape Town Convention 2001
} 
dalam konvensi ini. Namun, segala aturan dan ketentuan yang ada di dalam Konvensi Cape Town 2001 tidak secara langsung dan keseluruhan diterapkan pada masyarakat di Indonesia. Aturan dan ketentuan itu akan dimasukkan dan disesuaikan ke dalam hukum nasional Indonesia terlebih dahulu, sebagai peraturan perundang-undangan atau sebagai bentuk model pedoman ketentuan nasional. Karena, apabila tidak ada penyesuaian terlebih dahulu dan secara langsung diterapkan pada masyarakatnya, dikhawatirkan akan menjadi suatu masalah dalam penerapannya pada masa mendatang. Masalah utama yang dimaksudkan adalah permasalahan karena kurang cocoknya ketentuan internasional itu pada norma dan kebutuhan masyarakat Indonesia.

Alasan lain yang memperkuat bahwa pemerintah Indonesia perlu membuat peraturan nasional untuk melaksanakan Konvensi Cape Town 2001 adalah karena perjanjian internasional ini merupakan non-self executing treaties. ${ }^{23}$ Dan yang dimaksud dari non-self executing treaties dalam Konvensi Cape Town 2001 adalah perjanjian internasional yang tidak dapat dijalankan secara langsung tanpa adanya peraturan perundang-undangan nasional terlebih dahulu. Peraturan perundangundangan nasional yang mengacu pada pada perjanjian internasional tersebut dirasa penting karena akibat hukum dari non-self executing treaties pun tidak berlaku hanya pada negara saja tetapi juga mengikat terhadap hak warga negara masingmasing (individu).

Indonesia pertama kali meratifikasi Konvensi Cape Town 2001 melalui Peraturan Presiden No. 8 Tahun 2007. Dan melalui Peraturan Presiden, pemerintah Indonesia secara tidak langsung mengajukan deklarasi wajib (mandatory declaration) terkait ratifikasi atau mengadopsi Konvensi Cape Town 2001. Dalam Peraturan Presiden, Indonesia tidak mengadopsi ketentuan dalam Konvensi Cape Town 2001 secara keseluruhan, namun sudah dianggap meratifikasi Konvensi Cape Town 2001.

${ }^{23}$ Adi Prakoso Bintang, 'Konvensi Cape Town 2001' (SCRIBD 2018) <https://id.scribd. com/document/379094740/Konvensi-Cape-Town-2001-docx>, accessed on 15 Desember 2018. [5] 
Ketentuan pertama adalah Pasal 39 (1) poin (a), ${ }^{24}$ terkait dengan para pemegang kepentingan internasional yang terdaftar harus memiliki prioritas di antara kategori atas hak non-konsensual. Dalam hal ini yang dijadikan sebagai prioritas di antara hak non-konsensual adalah, hak gadai yang berkenaan dengan para pegawai perusahaan penerbangan atas upah-upah yang belum dibayarkan, dan hak gadai yang berkenaan dengan pajak-pajak yang atau beban utang yang belum dibayar berkaitan dengan penggunaan pesawat udara. Selanjutnya dalam instrumen hukum ini, Indonesia juga menyatakan mengadopsi Pasal 39 (1) poin (b), ${ }^{25}$ yaitu mengenai tidak adanya ketentuan konvensi yang dapat mempengaruhi hak dari negara atau lembaga negara atau jasa layanan umum swasta untuk menyita atau menahan objek berdasarkan hukum dari negara itu untuk membayar suatu jumlah utang yang berkaitan langsung dengan objek perjanjian atau objek lainnya.

Selain kedua poin pada Pasal 39 Ayat (1), pada Peraturan Presiden ini, Indonesia juga mendeklarasi bahwa terikat dan mengadopsi ketentuan yang ada di dalam Pasal 40, ${ }^{26}$ Pasal 53, ${ }^{27}$ dan Pasal 54 Ayat (2) ${ }^{28}$ Konvensi Cape Town 2001. Dalam Pasal 40 Konvensi Cape Town 2001 mengatur mengenai hak kepentingan

${ }^{24}$ Article 39 (1) point (a) - A Contracting State may at any time, in a declaration deposited with the Depository of the Protocol declare, generally or specifically: (a) those categories of non-consensual right or interest (other than a right or interest to which article 40 applies) which under that State's law have priority over an interest in an object equivalent to that of the holder of a registered international interest and which shall have priority over a registered international interest, whether in or outside insolvency proceedings;

${ }_{25}$ Article 39 (1) point (b) - That nothing in this Convention shall affect the right of a State or State Entity, intergovernmental organization or other private provider of public services to arrest or detain an object under the laws of that State for payment of amounts owed to such entity, organization or provider directly relating to those services in respect of that object or other object

${ }_{26}$ Article 40 - Registrable nonconsensual rights or interests

A Contracting State may at any time in a declaration deposited with the Depositary of the Protocol list the categories of nonconsensual right or interest which shall be registrable under this Convention as regards any category of object as if the right or interest were an international interest and shall be regulated accordingly. Such a declaration may be modified from time to time.

27 Article 53 - Determination of courts

A Contracting State may, at the time of ratification, acceptance, approval of, or accession to the Protocol, declare the relevant "court" or "courts" for the purposes of Article 1 (h) and Chapter XII of This Convention.

${ }^{28}$ Article 54 point (2) - A Contracting State shall, at the time of ratification, acceptance, approval of, or accession to the Protocol, declare whether or not any remedy available to the creditor under any provision of this Convention which is not there expressed to require application to the court may be exercised only with leave of the court. 
non-konsensual hampir sama dengan ketentuan yang ada di Pasal 39. Dalam Pasal 53 Konvensi Cape Town 2001, mengatur berkaitan dengan kompetensi pengadilan dan yurisdiksi hukum yang berwenang untuk mengadili apabila terjadi sengketa dalam transaksi pesawat udara. Pengadilan yang dimaksud pada Konvensi Cape Town 2001 khususnya pada Pasal 1 huruf h adalah suatu badan peradilan, badan administratif atau badan arbitrase yang dibentuk oleh negara anggota. Kedua pasal ini memberi kewenangan kepada negara anggota untuk menentukan pengadilan mana yang memiliki yurisdiksi untuk dapat memutus. Dan untuk Pasal 54 Ayat (2) Konvensi Cape Town 2001, Indonesia mendeklarasi mengenai pernyataan pemulihan bagi kreditor dari hasil putusan pengadilan langsung dapat dieksekusi tanpa harus adanya permohonan eksekusi kepada pengadilan yang memutus. ${ }^{29}$

Selain dari Konvensi Cape Town 2001, dalam Peraturan Presiden ini Indonesia juga mengadopsi beberapa ketentuan pelaksana dari Protocol to The Cape Town Convention 2001. Ketentuan yang diadopsi yaitu:

1. Pasal XXX Ayat (1) berkenaan dengan Pasal VIII terkait Pilihan Hukum;

2. Pasal XII tentang bantuan kepailitan atau insolvency;

3. Pasal XIII tentang kuasa untuk mengajukan permohonan deregistrasi atau penghapusan pendaftaran;

4. Pasal XXX Ayat (2) yang berkenaan dengan Pasal X tentang perubahan ketentuan pemulihan sebelum putusan akhir;

5. Pasal XXX (3) yang terkait dengan Pasal XI tentang pemulihan terhadap kepailitan atau remedies on insolvency.

Kemudian, Indonesia membentuk Undang-Undang No. 1 tahun 2009 (selanjutnya disebut Undang-Undang Penerbangan) sebagai pelaksana dari ketentuan yang diadopsi dari Konvensi Cape Town 2001. Dalam Undang-Undang Penerbangan ini terdapat beberapa pasal yang mengadopsi ketentuan yang ada di dalam Konvensi Cape Town 2001. Dalam Bab IX dari Pasal 71 sampai dengan Pasal 82 tentang Kepentingan Internasional atas Objek Pesawat Udara. Selain pasal-pasal yang mengatur mengenai kepentingan internasional, dalam UndangUndang Penerbangan juga terdapat beberapa ketentuan lain yang diadopsi dari 
Konvensi Chicago 1944, yaitu mengenai pendaftaran tanda kebangsaan bagi suatu pesawat udara. Seperti yang telah dijelaskan pada Bab II, bahwa terdapat dua macam pendaftaran bagi pesawat udara. Pertama, pendaftaran tanda kebangsaan yang diatur dalam Konvensi Chicago 1944 dan kedua, pendaftaran kepentingan internasional yang timbul dari perjanjian yang diatur dalam Konvensi Cape Town 2001. Ketentuan terkait pendaftaran tanda kebangsaan pesawat udara (meliputi juga ketentuan penghapusan pendaftaran pesawat udara) diatur dalam bab VII UndangUndang Penerbangan, pada Pasal 24 sampai Pasal 33.

Selanjutnya, dalam sistem peraturan perundang-undangan nasional, suatu undang-undang pada umumnya memiliki sebuah peraturan pelaksana, yaitu dalam bentuk peraturan menteri. Peraturan pelaksana dari Undang-Undang No. 1 Tahun 2009 tentang Penerbangan harus bersifat lebih teknis, khususnya terkait pendaftaran tanda kebangsaan pesawat udara. Berdasarkan fakta tersebut, yang menjadi sebab dibentuknya Peraturan Menteri Perhubungan No. KM 49 Tahun 2009 (tentang Peraturan Keselamatan Penerbangan Sipil Bagian 47 - Civil Aviation Safety Regulation 47 (selanjutnya ketentuan ini juga biasa disebut CASR 47 (terbaru Revisi ke-3))), sebagai bentuk peraturan pelaksana dari Undang-Undang Penerbangan.

\section{Kesimpulan}

Dalam Konvensi Cape Town 2001 terdapat ketentuan mengenai kepentingan internasional yang dapat timbul dari tiga perjanjian internasional, yaitu Security Agreement, Title Reservation Agreement, dan Leasing Agreement. Dan melalui perjanjian-perjanjian tersebut, timbulnya kepentingan internasional harus terlebih dahulu didaftarkan secara online yang dilakukan melalui website https://www. internationalregistry.aero/ir-web/. Berbeda dengan pendaftaran kepentingan internasional yang melekat pada pesawat udara, perusahaan maskapai penerbangan juga harus mendaftarkan pesawat udaranya untuk mendapatkan tanda kebangsaan, mengacu pada ketentuan yang ada di dalam Konvensi Chicago 1944. Dari kedua pendaftaran tersebut maka, pesawat udara memiliki dua registrasi yaitu registrasi kepentingan internasional dan registrasi tanda kebangsaan. 
Indonesia meratifikasi Konvensi Cape Town 2001, dalam bentuk peraturan perundang-undangan hukum nasional. Sebagai entry point, Indonesia meratifikasi Konvensi Cape Town 2001 dalam bentuk Peraturan Presiden No. 8 tahun 2007. Dalam Peraturan Presiden ini, tidak secara keseluruhan ketentuan konvensi diadopsi, ketentuan-ketentuan yang utama saja yang diadopsi. Selanjutnya, Indonesia membentuk Undang-Undang Penerbangan dan Peraturan Menteri (sebagai pelaksana Undang-Undang Penerbangan). Dalam Undang-Undang Penerbangan, mengatur terkait kepentingan internasional dan pendaftaran tanda kebangsaan yang melekat pada pesawat udara. Yang menjadi kelemahan dari Undang-Undang Penerbangan dan hukum nasional lainnya adalah belum adanya aturan secara spesifik mengenai leasing pesawat udara dan hak jaminan kebendaan atas pesawat udara. Kreditor dapat mengajukan IDERA dengan tujuan untuk melindungi hak dan kepentingan kreditor yang merasa dirugikan.

\section{Daftar Bacaan}

\section{Buku}

Donal Patrick Hanley, Aircraft Operating Leasing-A Legal and Practical Analysis in The Context of Public and Private International Air Law (Wolters Kluwer Law\&Business 2012).

Peter Mahmud Marzuki, Penelitian Hukum (Kencana Prenada Media 2005).

Prita Amalia, Industri Penerbangan di Indonesia (Refika Aditama 2016).

\section{Jurnal}

Roy Goode, 'The International Interest as an Autonomous Property Interest', (2004) I European Review of Private Law.

Saiful Anam \& Partners, 'Pendekatan Perundang-Undangan (Statute Approach) dalam Penelitian Hukum', (2017) 28 Legal Opinion. <https://www.saplaw. top/pendekatan-perundang-undangan-statute-approach-dalam-Penelitianhukum/>.

\section{Laman}

Ngobrolin Hukum, 'Pendekatan Dalam Penelitian Hukum' (Ngobrolin Hukum 
2013) <https://ngobrolinhukum.wordpress.com/2013/12/16/pendekatandalam-penelitian-hukum/>, accessed on 27 Juni 2019

Ireland Ibec, 'Iris Advantage - Reasons for choosing Ireland as a destination', (Aircraft Leasing Ireland Ibec 2018)

$<$ https://www.aircraftleasingireland.ie/Sectors/ALI/ALI.nsf/vPages/ Aircraft_leasing_in_Ireland irish-advantage!OpenDocument $>$, accessed on 10 Mei 2019

Adi Prakoso Bintang, 'Konvensi Cape Town 2001' (SCRIBD 2018) <https:// id.scribd.com/document/379094740/Konvensi-Cape-Town-2001-docx>, accessed on 15 Desember 2018.

International Aircraft Registry, 'International Registry of Mobile Assets)' $<$ https:// www.internationalregistry.aero/ir-web/>.

\section{Peraturan}

Konvensi Cape Town 2001 dan Protokol dari Konvensi Cape Town 2001

Lampiran Peraturan Presiden No. 8 Tahun 2007

HOW TO CITE: Erlisa Akhlakul Karimah, 'Sewa Guna Usaha Pesawat Udara Menurut Konvensi Cape Town 2001 dan Implementasinya dalam Hukum Nasional' (2019) Vol. 2 No. 5 Jurist-Diction. 